\title{
Response of maize seedlings to the latent zinc deficiency under different $\mathrm{Fe} / \mathrm{Zn}$ ratio
}

\author{
Nóra Bákonyi \\ University of Debrecen, Institute of Crop Science, Division of Agricultural Botany and Crop Physiology, \\ Böszörményi u. 138. H-4032 Debrecen, \\ nbakonyi@agr.unideb.hu
}

Keywords: latent Zn deficiency, Fe/Zn ratio, dry matter production, SPAD index

\section{SUMMARY}

Zinc $(Z n)$ deficiency is a critical nutritional problem for plants and peoples all over the world. Almost half of the world's cereal crops are deficient in Zn, leading to poor crop yield. In this study, the effect of different Fe/Zn ratio on some physiological parameters of maize seedlings were investigated on the dry matter of shoots and roots and their ratio, SPAD index and the total length of shoots.

The relative chlorophyll contents significantly decreased under increasing Fe given to the Zn deficient. The results showed that the different Fe/Zn supplies decreased the total length of shoots - ranging from 9\% to 65\% - by latent Zn deficiency. Corresponding to several scientific findings, it was observed that the non-optimal Fe/Zn ratio of tissues take part in the evolution of latent Zn deficiency in the case of high Fe concentration.

\section{INTRODUCTION}

One-third of the world's population is at risk of Zn deficiency in rates ranging from $4 \%$ to $73 \%$, depending on the given country. Several physiological processes will be damaged due to the absence of $\mathrm{Zn}$. There are number of physiological impairments in $\mathrm{Zn}$-deficient plant cells causing retardation of the growth, differentiation and development of plants (Cakmak, 2000), because the $\mathrm{Zn}$ is essential micronutrient for the plant via important enzyme-constituent and enzyme-activator. Zinc deficiency affected photosynthesis (Randall and Bouma, 1973).

Nambiar and Motiramani (1981) established that the Fe/Zn ratio in maize tissue appears to be a promising diagnostic tool for prediction of latent Zn deficiency. Gangwar and Mann (1972) suggested that the excess Fe can cause Zn deficiency in rice. According to Warnock (1970) the Fe concentrations were seven-times and the Mn concentration two-times higher than the control in $\mathrm{Zn}$-deficient plants. It was observed that the antagonism between $\mathrm{Fe}, \mathrm{Zn}$ and $\mathrm{Mn}$ lead to latent Zn deficiency in the case of high Fe concentration. Cakmak (2000) has published, that the uptake of $\mathrm{Fe}^{2+}$ is stimulated by $\mathrm{Zn}$ deficiency and in line with this the $\mathrm{Fe}^{2+}$ accumulates in toxic amounts in the shoots. In case of stress conditions - e.g. Zn deficiency - the accumulation of $\mathrm{Fe}^{2+}$ connect to demage of chloropylls.

\section{MATERIALS AND METHODS}

The experimental plant was maize (Zea mays L. cvs. Reseda SC.). The seeds were germinated on moistened filter paper at $25^{\circ} \mathrm{C}$. The seedlings were transferred to a continuously aerated nutrient solution of the following composition: $2.0 \mathrm{mM} \mathrm{Ca}\left(\mathrm{NO}_{3}\right)_{2}, 0.7 \mathrm{mM} \mathrm{K}_{2} \mathrm{SO}_{4}, 0.5 \mathrm{mM} \mathrm{MgSO}{ }_{4}, 0.1 \mathrm{mM} \mathrm{KH}_{2} \mathrm{PO}_{4}, 0.1 \mathrm{mM} \mathrm{KCl}, 1 \mu \mathrm{M} \mathrm{H}_{3} \mathrm{BO}_{3}$, $1 \mu \mathrm{M} \mathrm{MnSO}_{4}, 0.25 \mu \mathrm{M} \mathrm{CuSO}_{4}, 0.01 \mu \mathrm{M}\left(\mathrm{NH}_{4}\right)_{6} \mathrm{Mo}_{7} \mathrm{O}_{24}$. The iron was added to the nutrient solution as Fe-EDTA in a concentration of $10^{-4} \mathrm{M}$ in case of $1 \mathrm{x}$ Fe treatment. The zinc was applied in form of $\mathrm{ZnSO}_{4}$ in a concentration of $1 \mu \mathrm{M}$ in case of $1 \mathrm{x} \mathrm{Zn}$ treatment. The seedlings were grown under controlled environmental conditions (light/dark regime $16 / 8 \mathrm{~h}$ at $20-25{ }^{\circ} \mathrm{C}, 65-75 \%$ relative humidity and a photosynthetic photon flux density 300 $\mu \mathrm{mol} \mathrm{m} \mathrm{m}^{-2}$. The dry weight of shoots and roots were measured by OHAUS Explorer analytical balance and their ratio. The relative chlorophyll contents (SPAD index) were determined by MINOLTA SPAD 502 (Osaka, Japan) and the total shoots length by ruler. 15 different treatments were applied (Table 1).

Table 1

The different proportioned Fe/Zn treatments

\begin{tabular}{c|lc|cc|l} 
Number & Treatments & Number & Treatments & Number & Treatments \\
\hline $\mathbf{1}$ & Control & $\mathbf{6}$ & $1 \mathrm{xZn}+5 \mathrm{xFe}$ & $\mathbf{1 1}$ & $5 \mathrm{xZn}+10 \mathrm{xFe}$ \\
$\mathbf{2}$ & $-\mathrm{Zn}+1 \mathrm{xFe}$ & $\mathbf{7}$ & $1 \mathrm{xZn}+10 \mathrm{xFe}$ & $\mathbf{1 2}$ & $10 \mathrm{xZn}+-\mathrm{Fe}$ \\
$\mathbf{3}$ & $-\mathrm{Zn}+5 \mathrm{xFe}$ & $\mathbf{8}$ & $5 \mathrm{xZn}+-\mathrm{Fe}$ & $\mathbf{1 3}$ & $10 \mathrm{xZn}+1 \mathrm{xFe}$ \\
$\mathbf{4}$ & $-\mathrm{Zn}+10 \mathrm{xFe}$ & $\mathbf{9}$ & $5 \mathrm{xZn}+1 \mathrm{xFe}$ & $\mathbf{1 4}$ & $10 \mathrm{xZn}+5 \mathrm{xFe}$ \\
$\mathbf{5}$ & $1 \mathrm{xZn}+-\mathrm{Fe}$ & $\mathbf{1 0}$ & $5 \mathrm{xZn}+5 \mathrm{xFe}$ & $\mathbf{1 5}$ & $10 x \mathrm{x}+10 x \mathrm{xe}$
\end{tabular}

Remark: Bákonyi, N. 2011. 


\section{RESULTS AND DISCUSSION}

The effect of different Fe/Zn ratio was examined on some physiological parameters of maize seedlings. The high amount of iron induced latent $\mathrm{Zn}$ deficiency caused retardation in the development and growth of plants in accordance with the literature; therefore, the dry matter production of experimental plants were measured (Table 2).

The effect of different zinc ( $\mathrm{Zn})$ and iron (Fe) treatments on the dry matter of shoots and roots in the case of maize seedlings (gplant $\left.{ }^{1}\right)(\mathrm{n}=10 \pm$ s.e.). Significant difference compare to the control: $* \mathbf{p}<0.05, * * \mathbf{p}<0.01, * * * \mathbf{p}<0.001$.

\begin{tabular}{|c|c|c|c|c|}
\hline & \multirow{2}{*}{ Treatments } & \multicolumn{2}{|c|}{ dry weight } & \multirow{2}{*}{$\begin{array}{c}\text { shoot/root } \\
\text { ratio }\end{array}$} \\
\hline & & shoots & roots & \\
\hline 1 & Control & $0.68 \pm 0.29$ & $0.12 \pm 0.04$ & 5.58 \\
\hline 2 & $-\mathrm{Zn}+1 \mathrm{xFe}$ & $0.48 \pm 0.10 *$ & $0.11 \pm 0.04$ & 4.16 \\
\hline 3 & $-\mathrm{Zn}+5 \mathrm{xFe}$ & $0.30 \pm 0.09 * * *$ & $0.10 \pm 0.04$ & 3.04 \\
\hline 4 & $-\mathrm{Zn}+10 x \mathrm{xe}$ & $0.28 \pm 0.08 * * *$ & $0.07 \pm 0.02 * * *$ & 3.81 \\
\hline 5 & $1 x Z n+-F e$ & $0.29 \pm 0.07 * * *$ & $0.14 \pm 0.16$ & 2.05 \\
\hline 6 & $1 x Z n+5 x F e$ & $0.33 \pm 0.15 * *$ & $0.09 \pm 0.04$ & 3.56 \\
\hline 7 & $1 x Z n+10 x F e$ & $0.38 \pm 0.10 * *$ & $0.08 \pm 0.04 *$ & 4.63 \\
\hline 8 & $5 x Z n+-F e$ & $0.35 \pm 0.06^{* *}$ & $0.08 \pm 0.03^{* *}$ & 4.36 \\
\hline 9 & $5 x Z n+1 x F e$ & $0.68 \pm 0.13$ & $0.10 \pm 0.04$ & 6.53 \\
\hline 10 & $5 x \mathrm{Zn}+5 \mathrm{xFe}$ & $0.64 \pm 0.19$ & $0.12 \pm 0.04$ & 5.46 \\
\hline 11 & $5 x \mathrm{Zn}+10 \mathrm{xFe}$ & $0.61 \pm 0.17$ & $0.08 \pm 0.03 *$ & 7.20 \\
\hline 12 & $10 x Z n+-F e$ & $0.26 \pm 0.05 * * *$ & $0.06 \pm 0.01 * * *$ & 4.21 \\
\hline 13 & $10 x Z n+1 x F e$ & $0.53 \pm 0.29 * * *$ & $0.11 \pm 0.08$ & 4.77 \\
\hline 14 & $10 x \mathrm{Zn}+5 \mathrm{xFe}$ & $0.67 \pm 0.18$ & $0.11 \pm 0.05$ & 6.22 \\
\hline 15 & $10 x Z n+10 x F e$ & $0.56 \pm 0.28$ & $0.11 \pm 0.07$ & 5.22 \\
\hline
\end{tabular}

Remark: Bákonyi, N. 2011.

Table 2. demonstrates that the different Fe/Zn supply caused significant differences in comparison to the control. (In the case of $\mathrm{Zn}$ deficient treatments $(2,3,4)$ ). The dry weight of maize seedlings decreased in line with the increasing Fe doses. The highest Fe dose without $\mathrm{Zn}$ treatment $(-\mathrm{Zn}+10 \mathrm{xFe}$ treatment) retarded the dry weight of shoots and roots by $59 \%$ and $42 \%$, respectively. When $\mathrm{Zn}$ also was given into the nutrient solution there was no observed relationship among the treatments. Mostly the absence of Fe caused decrease in the dry weight. In addition to the $\mathrm{Zn}$ deficient treatment, the single $\mathrm{Zn}$ amount $(1 \mathrm{xZn})$ with increasing Fe doses also significantly decreased the dry weight of shoots and roots as well. The shoot/root ratio shows, that the overdose of $\mathrm{Zn}$ and Fe can increase the weight of shoots and decrease the the weight of roots in comparison to the control.

$\mathrm{Zn}$ is known as a functional component of a number of enzymes, which play significant role in protein synthesis. The photosynthetic pigments contain a chromofore group and a protein part; therefore, protein synthesis is retarded in lack of $\mathrm{Zn}$ and the pigments can suffer damage. The relative chlorophyll contents were measured to examine the possible effect of Fe deficiency or excess beside different Zn supply. 
Figure 1: The effect of different zinc ( $\mathrm{Zn})$ and iron (Fe) treatments on the relative chlorophyll contents of second leaves in case of 14day-old maize seedlings (SPAD units) $(n=18 \pm$ s.e.). Significant difference compare to the control: $* p<0.05, * * p<0.01, * * * p<0.001$.

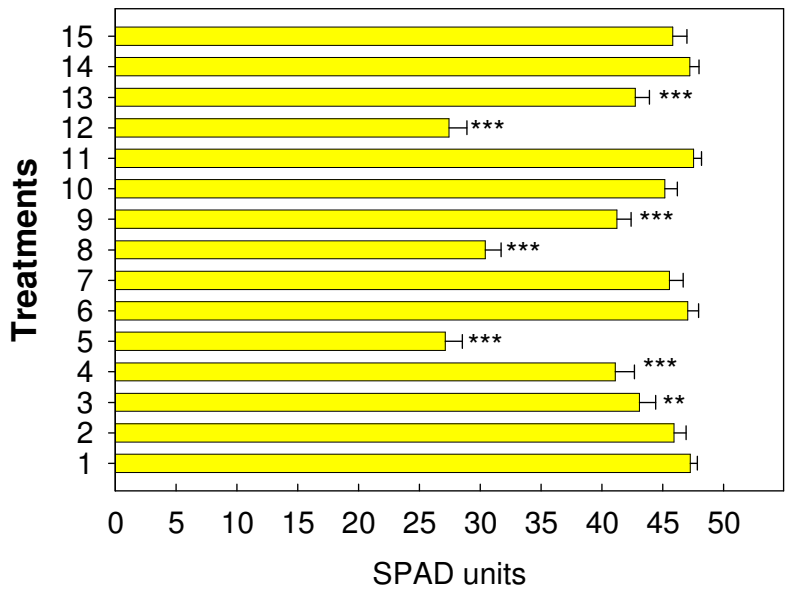

Remark: Bákonyi, N. 2011.

The absence of Fe caused the highest (close to 50\%) reduction in SPAD index $(5,8,12$ treatments), because the $\mathrm{Fe}$ has a very important role in photosynhetical processes (Figure 1). The relative chloropyll concents decreased under increasing Fe doses in $\mathrm{Zn}$ deficient nutrient solution in the second leaves of maize seedlings, because in case of $\mathrm{Zn}$ deficiency the uptake of Fe is enhanced and the Fe accumulates in toxic amounts in the shoots, and as a consequence the chlorophyll contents will be decreased (Cakmak, 2000).

According to several scientists, the non-optimal concentration of Zn and Fe can cause Zn deficiency in plant tissues and, as a consequence, the internodes of shoots get shorter and the plant will be dwarf, which can be an evidence of retarded auxin synthesis (Kalocsai, 2006). Based on this observation, the elongations of plants synchronize with the auxin contents of shoots. To prove this hypothesis, the total length of shoots was measured, and to determine the possible effect of latent $\mathrm{Zn}$ deficiency caused by different Fe/Zn ratios (Figure 2).

Figure 2: The effect of different zinc ( $\mathrm{Zn})$ and iron (Fe) treatments on the total length of shoots in the case of maize seedlings (cm plant $\left.^{-1}\right)(\mathrm{n}=8 \pm$ s.e. $)$. Significant difference compare to the control: $* \mathbf{p}<0.05, * * p<0.01, * * * p<0.001$.

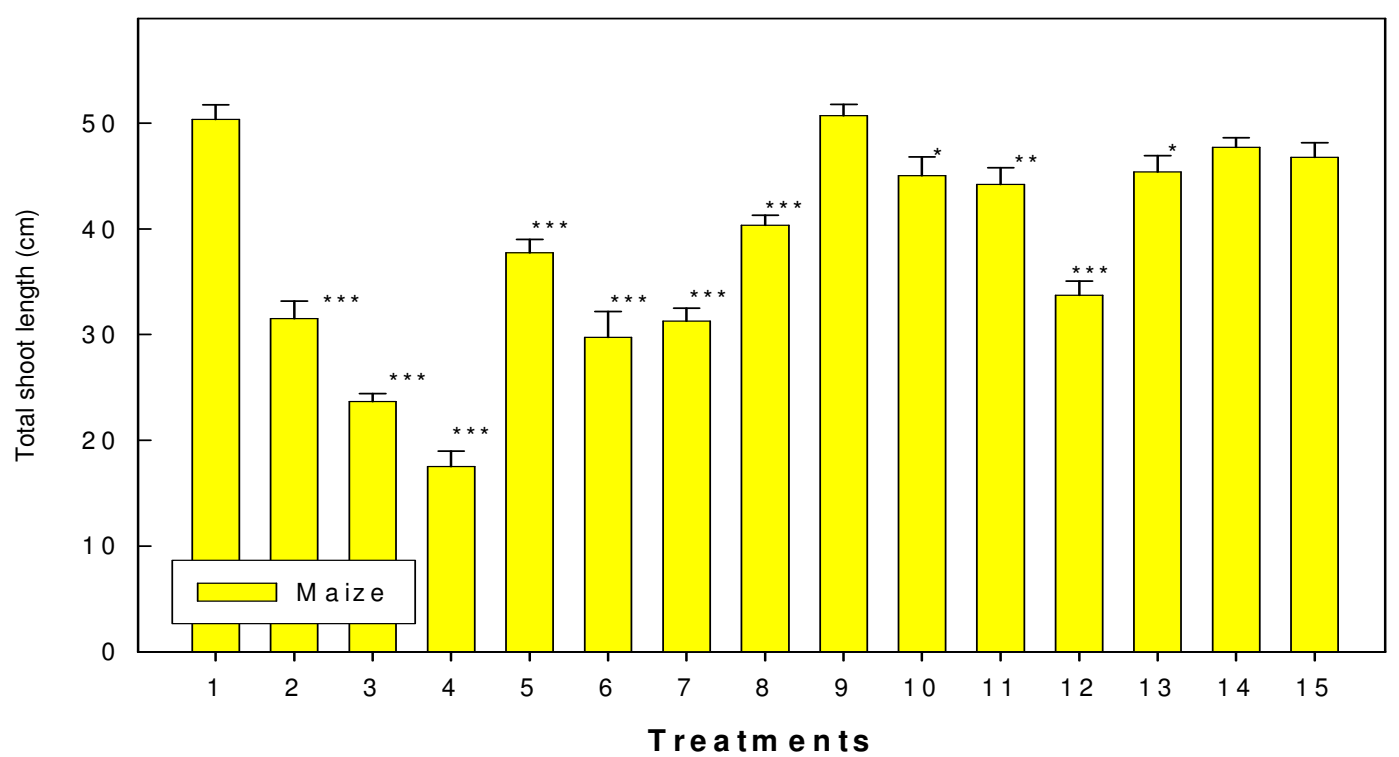

Remark: Bákonyi, N. 2011.

Figure 2. presents the clear effect of increasing Fe doses given to the $\mathrm{Zn}$ deficient nutrient solution, as a result the length of shoots significantly decreased paralell with the increase of Fe doses, which shows that latent 
$\mathrm{Zn}$ deficiency was evaluated. The effect of treatment 4 was the strongest, because in this case, the lowest $(15.54 \pm 3.48)$ total shoot length was measured in comparison to the control $(44.96 \pm 3.60)$. The total lengths of shoots were decreased (ranging from 9\% to 65\%) in all cases except of treatments 9, 14, 15, where the plants were treated with higher, or with the same Zn dose than Fe.

\section{CONCLUSIONS}

Corresponding to findings by Cakmak (2000) and Warnock (1970), it was observed that the non-optimal $\mathrm{Fe} / \mathrm{Zn}$ ratio of tissues leads to latent $\mathrm{Zn}$ deficiency in the case of high Fe concentration. The dry matter of shoots and roots dramatically decreased when the highest Fe/Zn ratio was applied. We suppose that the reason for this is the latent $\mathrm{Zn}$ deficiency that was caused by high Fe contents.

According to our results, the relative chlorophyll contents (SPAD index) decreased under increasing Fe doses given to the $\mathrm{Zn}$ deficient nutrient solution because of the enhanced Fe accumulation lead to decrease of chlorophyll contents. The latent $\mathrm{Zn}$ deficiency appeared in the growth of plants. The different amounts of Fe decreased (ranging from $9 \%$ to $65 \%$ ) the length of shoots when $\mathrm{Zn}$ deficient treatments were applied and as a consequence, the growth of plants indicated the evolution of latent $\mathrm{Zn}$ deficiency.

\section{REFERENCES}

Cakmak, I. (2000): Possible roles of zinc in protecting plant cells from damage by reactive oxygen species. New Physiology 146, pp. 185-205.

Gangwar, A. M. S.- Mann J.S. (1972): Zinc nutrition of rice in relation to iron and manganese uptake under different water regimes. Indian Journal of Agricultural Science 42:1032-1035.

Kalocsai, R. (2006): A cink (Zn). MezöHír X. évf. 2006. szeptember p. 38.

Nabiar, K. K.-Motiramani, D. P. (1981): Tissue Fe/Zn ratio as diagnostic tool for prediction of $\mathrm{Zn}$ deficiency in crop plants (in maize) Plant and Soil. 1981. 60: 357-367.

Randall P. J.-D. Bouma. (1973): Zinc Deficiency, Carbonic Anhydrase, and Photosynthesis in Leaves of Spinach. Plant Physiology 52, 229-232.

Warnock, R. E., (1970): Micronutrient uptake and mobility within corn plants (Zea mays L.) in relations to phosphorus-induced zinc deficiency. Soil Sci. Soc. Amer. Proc. 34. pp. 765-769. 